\title{
Historic Urban Landscape and the Character of George Town, Penang UNESCO World Heritage Site
}

\author{
Shuhana Shamsuddin ${ }^{1}$,Ahmad Bashri Sulaiman ${ }^{2}$, Rohayah Che Amat $^{3}$ \\ ${ }^{1}$ Assoc. Prof, PhD. \& 2Prof., PhD. , Department of Civil Engineering (Built Environment), Razak School of UTM in \\ Engineering \& Advance Technology, \\ UTM International Campus Jalan Semarak, 54100 Kuala Lumpur \\ ${ }^{3} \mathrm{PhD}$. Candidate, Faculty of Built Environment, \\ Universiti Teknologi Malaysia (UTM), Skudai 83300 Johor, Malaysia
}

c.rohayah@yahoo.co.uk

\begin{abstract}
The increasing intervention from high rise construction and new developments within the historic urban fabric are threatening the existing character and the Outstanding Universal Value of UNESCO (United Nations Educational, Scientific and Cultural Organization) World Heritage Site List. This paper propagates that through the identification of historic urban landscapes that influence the character of the George Town world heritage sites, we are able to understand the relationships between the landscape components and the importance of historic characters of the sites. The methodology of this paper is based on written descriptions and site visual observations. The outcome of this paper reveals the significance of tangible and intangible factors that influence the urban landscape character of the case study area.
\end{abstract}

Keywords: Keywords: Type your keywords here, separated by semicolons ; Historic Urban Landscape; Character; World Heritage Site; Tangible and Tangible Factors

eISSN 2514-751X @ 2018. The Authors. Published for AMER ABRA cE-Bs by e-International Publishing House, Ltd., UK. This is an open-access article under the CC BY-NC-ND license (http://creativecommons.org/licenses/bync-nd/4.0/). Peer-review under responsibility of AMER (Association of Malaysian Environment-Behaviour Researchers), ABRA (Association of Behavioural Researchers on Asians) and $c E-B s$ (Centre for EnvironmentBehaviour Studies), Faculty of Architecture, Planning \& Surveying, Universiti Teknologi MARA, Malaysia.

DOI: https://doi.org/10.21834/aje-bs.v3i9.297 


\subsection{Introduction}

The impact of contemporary development on the overall urban landscape and its heritage significance was discussed by the World Heritage Committee since 2003. The Vienna Memorandum is an integrated approach that links contemporary architecture, sustainable urban development and landscape integrity which is based on existing historic patterns, building stocks and context. In 2005, a Declaration on the Conservation of Historic Urban Landscapes based on the Vienna Memorandum was adopted.

The desire to construct a location to be more acceptable to the tourists, global pressures and processes of urbanization has a direct impact on the local identity, visual integrity, its setting and the people who live in the historic cities. There is also concern on several urban management issues such as, the urban setting (old and new development pressures), urban context (loss of tradition and continuity), limitation of acceptable changes between conservation areas (of historic cities) and development districts, inconsistency in the scientific assessment of conserving urban areas and the urban values itself.

\subsection{Literature Review}

\subsection{Historic Urban Landscape (HUL)}

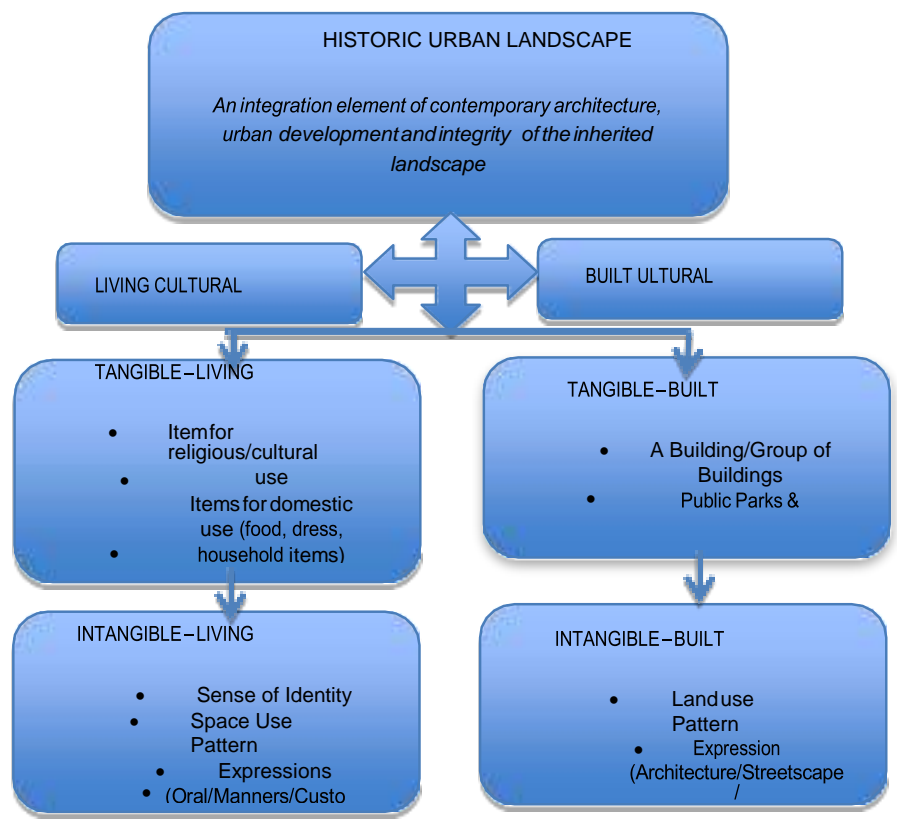

Fig. 1: Historic Urban Landscape Elements (adapted from Vienna Memorandum , 2005) 
Historic Urban Landscape refers to the sensory perception of the urban system such as urban layout, setting, plot system, building, open spaces, trees, vegetation and urban furniture. The concept of historic urban landscapes (HUL) contributes to the process of linking the tangible and intangible heritage components and the assessment of our understanding towards the towns or urban areas (ICOMOS, 2008). The historic urban landscape is an urban area resulting from the historic layering of cultural and natural values which extends beyond the notion of "historic center" or "ensemble". The elements in the historic urban landscape also include the site's topography, geomorphology and natural features, built environment, infrastructures, open spaces and gardens, land use patterns and spatial organization, visual relationships, and the urban structure. These also include the social and cultural practices and values, economic processes, as well as the intangible dimensions of heritage that is related to diversity and identity. Landscape is classified and described in cultural terms as a cultural environment that evolves with the natural environment. A cultural landscape is defined as a combination of nature and man-made works (ICOMOS, 2005) by emphasizing on the structural and harmonious interaction between man and their environment.

\subsection{Methodology}

\subsection{Case Study}

George Town was the first British port town that has a unique architectural and cultural townscape in the East and Southeast Asia (UNESCO, 2008). George Town and Malacca were formally inscribed as a UNESCO (United Nations Educational, Scientific and Cultural Organization) World Heritage Site on $7^{\text {th }}$ of July 2008 as "Historic Cities of the Straits of Malacca". This heritage site is the oldest British colonial town in South East Asia. The heritage site is enclosed by Light Street, Beach Street, Chulia Street and Jalan Kapitan Keling. These streets form the main commercial district of the city. The case study areas cover a core zone area of 109.38 hectares and the buffer zone covers an area of 150.04 hectares.

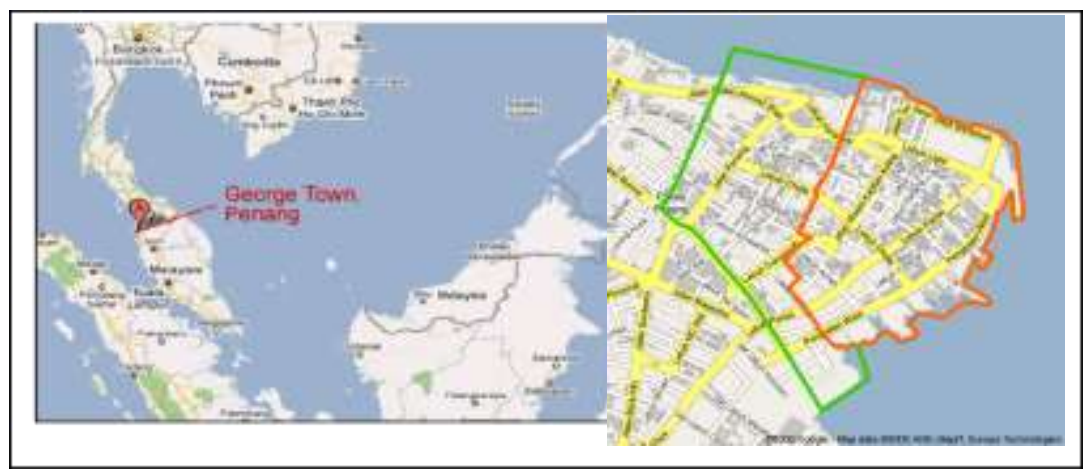

Fig. 2: The map of case study, George Town World Heritage Site 


\subsection{The Method}

This research employs several techniques such as a literature review of secondary data in the archive department, museum, public library and the local authority. A content analysis is done to examine the secondary information such as records about the history, structure plan, vision, and regulation, policies, issues, statistics, government publications (e.g. National Heritage Act, National Urbanization Policy, George Town Management Plan, George Town Local Plan and Special Area Plan), local media newspaper articles and publications from UNESCO World Heritage Convention, Charters, English Heritage Trust. A visual survey of the site was conducted to describe and explain the historic character of the case study area by identifying the elements that contribute to its character.

\subsection{Results and Discussion}

George Town was formerly known as Tanjung Penaga and named after the Penaga tree. This historic commercial town and port city was built by Francis Light and located between Light Street, Beach Street, Malabar Street (be called as Chulia Street) and Pit Street. The concept of George Town's development is based on informal gridiron layout that was inherited from the secondary towns of Roman city's planning. The British contributed a significant impact to the formation of urban patterns and transport access of George Town (Hassan, 2009). The immigration of traders from Asia and Europe has created a multicultural identity with the tangible and intangible heritage from different ethnic groups of the community, religious pluralism, variety of shop houses and religious buildings. George Town's urban pattern was derived using the Roman grid system which has a center point and two main roads, Cardo and Decumansu generated from this point. These two main roads served as the main streets and expanded into a grid design layout. In George Town WHS, the two main roads that were built is the Cardo (North South) in Weld Quay (Pengkalan Weld) and the Decumansus (East West) in Light Street (Lebuh Light).
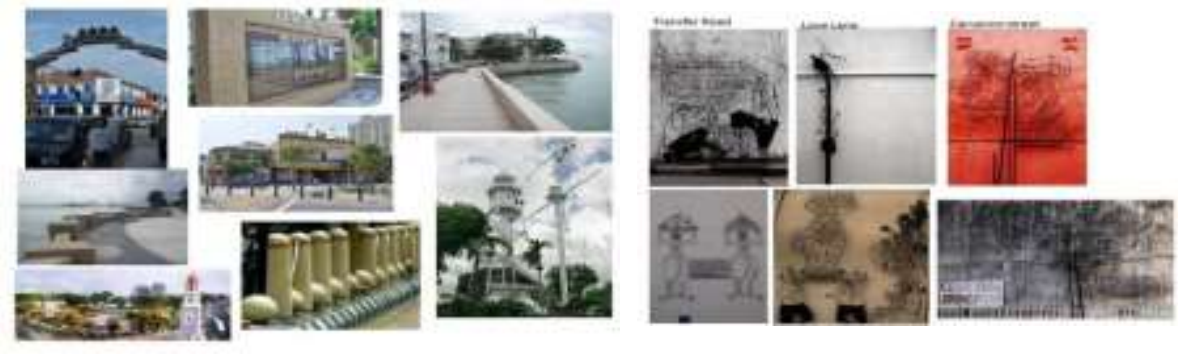

Fig. 3: Small scale elements or designed ornaments are important components in the town. The decoration makes this historic city becomes more attractive and adds value to the character of the place. The moderate designs of these elements blend harmoniously with the historic urban landscape of George Town WHS.

Burke and Ewan (1999) stated that open spaces contribute to the quality of life. The most 
dominant landscape element in George Town is the water bodies where it is located by the sea, the Straits of Malacca. Many of matured trees can be seen at Jalan Masjid Kapitan Keling, Esplanade and Padang Kota Lama where a different character is observed. The trees are planted surrounding the "Padang", creating a green pocket space within the area. Trancik (1986) stated that the trees and plants can provide the physical identity to a place by acting as the boundary to the place.

Padang Kota Lama and Esplanade are the historical open spaces in George Town. The Padang is used as a field for football, cricket and other sports. The Esplanade was an area for an evening stroll during the colonial era (Shuhana, 2011; Khoo \& Wade, 2003; Gardner, Sidisunthom \& Lai, 2011) and has meanings that are associated with the Fort Cornwallis (Shuhana, 2011). The activities conducted at this historical Padang and Esplanades contributed significantly towards the visual and sensory experience of the townscape (Shuhana, 2011). Currently, the activities that take place in this area are the Speakers' Square (Dataran Pidato), created by the local authority in order to allow people to have the freedom to give a speech and assemble. This place also becomes a node where people gathers especially during the weekends and weekday afternoon besides being a tourist attraction for the historic area (Fort Cornwallis).

Townscape refers to the totality of the material (tangible) cultural heritage site and elements of urban settlement (Shuhana, 2011). Historically, George Town was built on a swampy land and became a British colony in 1867 (Majlis PerbandaranPulau Pinang, 2011). The British administration was responsible in setting up the Public Department Works. Then, the area becomes occupied with channelized streams and rivers, hospitals, police stations, establishment of multi-cultural architectural forms, reclamation works, roads construction and ports activities. Its multi-cultural trading activities contributed towards the cultural tangible and intangible heritage of this historic city. The townscape qualities of George Town World Heritage Sites and its splendid setting can be appreciated from a variety of levels and distances, to panoramas and local vistas. The scenery is an important element of the Historic Urban Landscape. This element (views and scenery) represents the history and geographical background of the place. The sea view is the most significant element that contributes to the character of George Town's townscape. The hills and the straits remain the strong topographical elements that portray the identity of George Town.

Nasar (1979) in Shuhana (2011) states that the streets and the streetscape are important elements that shaped the character of the urban areas. The qualities of urban space give a significant impact to the townscape and influencing the identity of place. Historically, there were eight zones during the colonial era: (1) British Administration and Settlements; (2) Indian Hindu Settlement; (3) Fort and Financial Area; (4) Indian Muslim Settlement; (5) Malay Settlement; (6) Chinese Settlement (East); (7) Chinese Settlement (North); (8) Commercial Area and Market Place (Hassan, 2009). George Town did not have formal segregation or clear boundaries between different communities within the spaces or streets. The streets in George Town are named after the ethnic group (i.e. Malay Street, Chulia Street, Acheen Street, China Street, Armenian Street etc.); resemblance of British's empire (i.e. King Street, Victoria Street, Campbell Street, Downing Street etc.); and leading significant individual and administrator (i.e. Bishop Street, Light Street, etc.). Khoo (1997) identifies two aspects that 
influenced the character of the case study: (a) Rent Control Act (1948) which provides cheap housing and commercial spaces for the locals. (b) The decline of port activities that affects the entre-port trade activities. Each trade was embodied in specific cultural form and portrays the segregation of streets' activities and character where the Eurasians settled at Bishop and Church Street, the Chinese in China Street and the Indian Muslims in Chulia Street.

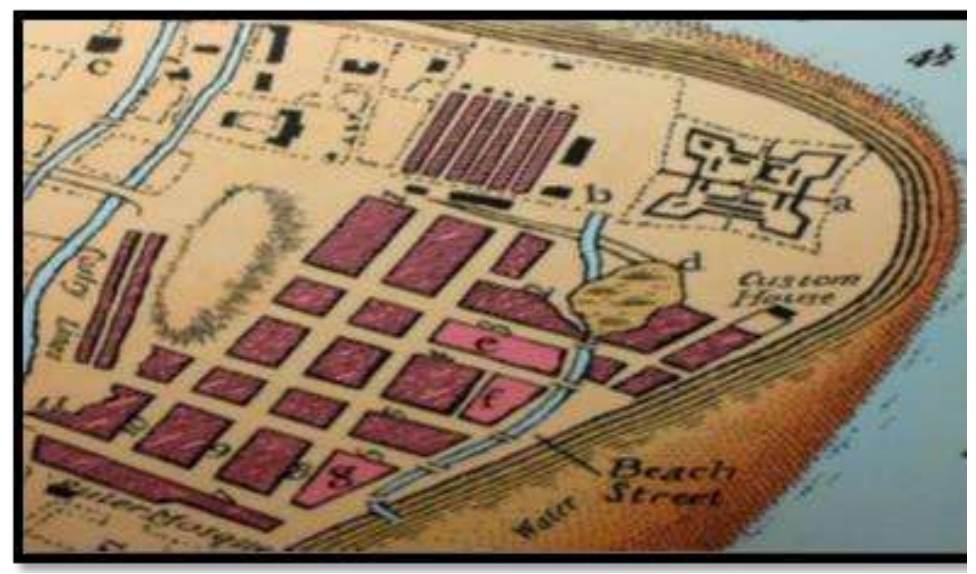

Fig. 4 :Propham Map 1798 (above) shows the early development of George Town (Source : Muzium Malaysia). The map depicts the population segregation in George Town such as Light Street occupied by merchants from East India Company; inner trading area for variety ethnic backgrounds;

Eurasian from Kedah settled at Lebuh Bishop and Lebuh Gereja and Indians occupying Lebuh Gereja.

The heritage buildings in George Town represent $24.3 \%$ of the overall number of historic pre-war buildings in the nation (Badaruddin \& Rahmat, 2005), with the World Heritage Site having more than 4,000 old buildings. Shuhana (2011) states that buildings are very prominent in the physical environment that contributes to the identity of towns and cities. The historical shophouses was characterized by eleven distinctive architectural styles and features that represent different periods of development. Since 1969 the water village's residents have been given the permission by the State Government a "Temporary Occupation License" to occupy these water villages (Majlis Perbandaran Pulau Pinang, 2011). Although the clan jetties (Weld Quay) along the waterfront have physically survived from threats of urbanization and development, their social-cultural composition has now been transformed and will eventually disappear. This area is now a low-income urban community settlement instead of a historic waterfront legacy lineage (clan) with its own identity and communal site of floating dwellings (water villages).

The skyline is derived from the viewpoint of cultural landscape (Sirisrisak, 2007) where Collins Cobuild English Dictionary defined it as "the line or shape that is formed where the sky meets buildings or lands". The height control is important to ensure the visual legibility of the important landmarks and continuity of the roofscape. The skyline is the line created by 
different outlines of man-made structures that can be viewed from far (Shuhana, 2011). In order to tackle the issue of safeguarding the historic skyline, UNESCO Regional Conference of World Heritage List (2007) states that maintaining the current differential height regulations for new constructions within and around the city is important in order to conserve or preserve the unique characteristics of the area.

George Town as a trading port has brought a large number of traders from the northern region of Sumatera, Malay Peninsula, India, China and Arab. This phenomenon has created a multi-cultural dimension that unites people from various cultural backgrounds (Majlis Perbandaran Pulau Pinang, 2011). The intermarriage between immigrants and local people has resulted in a cultural hybrid (i.e. Jawi Peranakan, Baba Nyonya, Indian Muslim), multicultural architectural design, interior furnishing, dress, foods and other elements that reflect the lifestyle of local people. Apart from being a commercial and religious center, George Town is also the birth place for multi-cultural communities. The communities are located in different streets with no formal segregation between them, hence creating distinctive multicultural activities and lifestyle. The urban spaces in George Town have double symbolic values, which portray the personal spaces and social spaces.

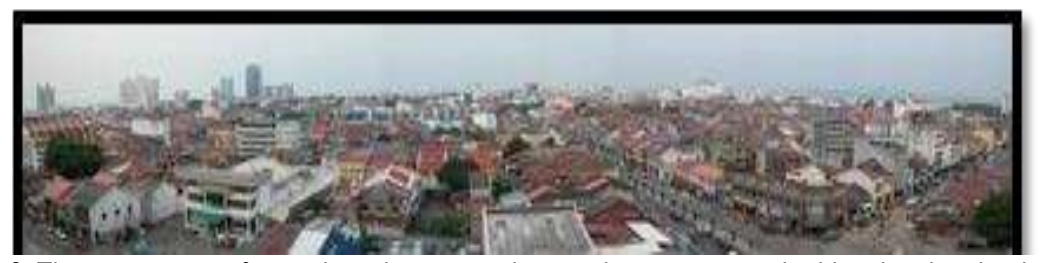

Fig.6: The terracotta roofscape is an important element that represents the historic urban landscape of George Town. The roofscape is attached to the temples and shop houses with inner courtyards, gables, hip-roof bungalows minarets and domes.

\subsection{Conclusion}

The significance of the world heritage site lies in its ability to retain the authenticity of its heritage value and the uniqueness of its townscape character. As the landscape elements are significant aspects that constitute the townscape, it is imperative that the landscape elements be protected in order to preserve the character of the area. The protection of the urban landscape elements will help to sustain the character of the UNESCO's World Heritage Sites. This is done by identifying the heritage physical elements that are created by human interactions with their environment. This helps to define the character of the local community as well as reflecting its past history. The landscape components, elements or meaning has often been overlooked in assessing the character of historic areas. It is also seldom addressed in the urban management and planning of cities especially in Malaysia. In order to have a more effective conservation of historic towns and areas, the historic urban landscape should become an integral part of the coherent policies of economic and social development of the urban and regional planning actions at every level. 


\section{Acknowledgement}

We would like to thank Universiti Teknologi Malaysia for funding this research.

\section{References}

Badaruddin, M \&Rahmat, A.M. (2005). Heritage Tourism In A Multicultural Society : The Case of Malaysia. 3rd Global Summit on Peace through Tourism Program Proceeding on $2^{\text {nd }}-5^{\text {th }}$ October 2005 at Royal Cliff Beach Resort, Pattaya Thailand. page 141-147

Brunetta, G and Voghera, A (2008). Evaluating landscape For Shared Values : Tools, Principles \&Methods. Landscape Research Vol 33 No 1. 71-87, February 2008

Countryside Agency \& Scottish Natural heritage, Interim landscape Character Assessment Guidance (1999)

Dyson-Bruce, L. (2003). Historic Landscape Assessment : The East of England Experience paper Product to GIS Delivery. Journal of GIS In Archaeology Volume 1 (April 2003) ESRI : New York.

Gardner, S, Sidisunthorn, P \& May, E. L (2011). The Heritage trees of Penang. Areca Books : Penang.

Garnham, H.L. (1985). Maintaining The Spirit of Place : A Process For The Preservation Of Town Character. Arizona : PDA Publishers

Hassan, A.S (2009). The British Colonial Divide and Rule Concept In Inner City Of George Town, Penang. Its Influence To Irregular Layout Of The Transport Access. International Journal of Transportation.International Journal of Transportation.Springer Science \& Business Media LLC.Vol 36, No. 3, pp 309-324.

ICOMOS' Observations On The Information Document by the World Heritage Centre on the Development of a revised UNESCO Recommendation on The Conservation of Historic Urban Landscapes, February 2008 ICOMOS,. Paris.

Jokiletho, J (2010). Notes On Definition And Safeguarding of HUL. Cities \& Times 4 (3):4

Khoo, S.N. (1993). Streets of George Town, Penang. Janus Print \&Resources : Penang

Khoo, S.N. \& Wade, M (2003).Penang : Postcard Collection 1899 -1933s. Janus Print \&Resources : Penang

Mann, W.A. (1993). Landscape Architecture : An Illustrated History In Timelines, Site Plans \& Biography. New York : John Wiley and Sons, Inc

Riksantikvaren (2010). Sustainable Historic Towns : A Handbook about DIVE - Urban Heritage Analysis. Norway :Postboks

Rippon, S (2011). Tool Kit : A Methodology For Assessing Historic Landscape Character - Our Wetland Heritage : An Intergrated Approach Towards Managing Coastal Landscape.

Shuhana, S (2011). Townscape Revisited :Unravelling The Character of Historic Townscape In Malaysia. Johor :Penerbit UTM Press

Sirisrisak, T \&Akagawa, N (2007). Cultural Landscape In The World Heritage List : Understanding on The Gap and categorization. City \& Time 2(3) : 2 
Swanwick, C \& Land Use Consultants.(2002). Landscape Character Assessment. Guidance For England \& Scotland. Cheltenham \&Edinburgh : The Countryside Agency \& Scottish Natural Heritage

The Secretary of The Interior's : Guidelines For The Treatment of Cultural Landscapes (1995). National Park Service, US Department of Interior. Federal Register Vol. 60 No 133

The World Heritage Centre, The State parties of World Heritage Convention, The World Heritage Committee, The Advisory Meetings at Jerusalem (June 2006), Saint Petersburg, Russian federation (January 2007), Olinda Brazil

(November 2007), UnescoHeadquaters (September 2006 \& November 2008) on Historic Urban Landscape Initiative (HUL)

UNESCO, Vienna Memorandum on World Heritage \& Contemporary Architecture - Managing Historic Urban Landscape, World Heritage Centre Paris, 20th May 2005

World Heritage Centre (2003). Cultural Landscapes : The Challenges of Conservation Paris, Unesco World Heritage Paper 7

World Heritage Centre (2003). Operational Guidelines For The Implementation of The World Heritage Convention Revised edition 2005, Paris (WHC 05/2, 2 February 2005) 